\title{
The scope of political jurisdictions and violence: theory and evidence from Africa
}

\author{
Jordan Adamson ${ }^{1}$ [D
}

Received: 25 July 2019 / Accepted: 3 December 2019 / Published online: 16 December 2019

(c) The Author(s) 2019

\begin{abstract}
Is there more violence in areas with many small countries or only a single large one? I build on Bernholz (The international game of power: past, present and future 1985) to create a unifying framework where both internal and external contestants engage in conflict, and then summarize how the spatial configuration of countries affects all types of violence with the Herfindahl-Hirschman Index of state sizes. Empirically, I examine fatalities from the conflict in Africa, where I use the borders set by the colonial powers of Europe to identify the effect of concentration. I find the most fatalities in areas with many small countries, but that violence decreases with concentration at a decreasing rate and eventually increases in areas with only one large country. These findings suggest an important difference between the observed average effect of concentration on violence and the expected marginal effects of further concentration.
\end{abstract}

Keywords Geopolitical concentration · Internal violence $\cdot$ External violence

JEL Classification D74 $\cdot \mathrm{H} 11 \cdot \mathrm{R} 12$

If a republic be small, it is destroyed by a foreign force; if it be large, it is ruined by an internal imperfection. - Montesquieu, 1748.

Thanks to William Shughart II, Arye Hillman, two anonymous referees, Patrick Warren, Robert Fleck, David Rojo-Arjona, Andrew Hanssen, Robert Tollison, Daniel Wood, William Dougan, Avner Seror, Jacob Burgdorf, and Ben Schwall for comments and suggestions. Thanks also to members from the 2019 Silvaplana workshop on Political Economy, the 2018 Smith Institue Workshop, the 2016 Clemson Workshop in Public Economics, and the SIOE 2016 Conference. A version of this paper was formerly circulated under the title 'Political Violence and the Geographic Concentration of Countries'.

Jordan Adamson

jordan.adamson@growthopportunity.org

https://sites.google.com/view/jordan-adamson

1 Center for Growth and Opportunity, Utah State University, Logan, USA 


\section{Introduction}

Africa is a continent riddled by war, and various leaders have proposed political unification to quell the conflicts. Yet it is far from obvious that a more politically unified Africa would reduce violence. The Democratic Republic of Congo, for instance, covers a space almost the size of Western Europe and has been filled with fighting - and this could worsen under a larger national jurisdiction. Moreover, the Congolese conflicts lay at the heart of Africa's world war which dwarfed the border violence between smaller countries (such as those between Djibouti and Eritrea). In this paper, I examine whether having fewer larger countries in a region mitigates or exacerbates conflict in Africa. In doing so, I provide a general framework for examining how the size distribution of countries affects the overall level of violence.

Reducing violence is a basic justification for the state and fundamental for economic development. ${ }^{1}$ Most scholars argue that more countries will create more conflict because there are more combatants and contestants (Hirshleifer 1995; Alesina and Spolaore 2005; Konrad and Skaperdas 2010; Powell 2013). Robbins (1939), for example, argued "the ultimate condition giving rise to those clashes of national economic interest which lead to international war is the existence of independent national sovereignties". Yet conflict between countries is only one part of the picture and we should be skeptical that continental unification necessarily brings peace-less still "a single supreme world government" (Russell 1936). If the world was composed of only a single country, then there would not be any fighting between countries. But that does not imply there would be world peace.

Another group of scholars has argued that larger countries have more internal conflicts because more predatory governments and rebel insurrections (Waltz 1979; Snidal 1985; Buhaug and Gates 2002; Buhaug 2006; Lacina 2015; Quinn 2015; Spolaore 2016). Tilly (1990), for example, argued that enemies of the state would be more likely to ally under larger jurisdictions to resist the concentrated coercion of a rent extractor. Furthermore, other scholars have suggested that smaller countries can better police and govern an area (Herbst 2000; Fleck and Hanssen 2013) and mitigate conflict spillovers (Silve and Verdier 2018). But this too is only one part of the picture. Breaking up states to reduce civil conflict could create external tensions or simply re-code internal fighters as external fighters without any meaningful change in behavior.

We do not know if there will be less violence with a single large country or a multitude of tiny ones because the literature is disconnected. By constricting their focus, scholars have precisely identified many important relationships (Verwimp et al. 2018): national neighbors are more likely to fight for territory (Toft 2014), divided ethnic groups are violent when far from the political capital (Michalopoulos and Papaioannou 2016), and fighting over resources is affected by border distances (Berman et al. 2017). Yet we still do not know if there will be less violence with a single large country, one country for each ethnicity, or countries large enough to engulf resource basins. There is a "gap between the analysis of interstate and intrastate war" (Levy and Thompson 2010) that is becoming ever more apparent. Scholars have now documented important conflict interdependencies (Prunier 2008; Köonig et al. 2017) and question "whether there is any justification for separate

\footnotetext{
1 Hamilton (1787) argued that "If these States should either be wholly disunited, or only united in partial confederacies, the subdivisions into which they might be thrown would have frequent and violent contests with each other."
} 
study of war types" (Cunningham and Lemke 2013). ${ }^{2}$ Gleditsch (2017) said it is generally "misleading to see these [internal] conflicts as purely domestic" and Gersovitz and Kriger (2013) specifically argued "the academic literature, both qualitative and quantitative, has mislabeled most episodes of large-scale violence in Africa as civil wars". The wars in Angola and Darfur, with many different types of contestants fighting in their large territories, is just one example. ${ }^{3}$ Scholars dice the data into exclusive categories to avoid a "lack of theory" (Starr 1994) or, more recently, a precisely identified mechanism. But we might gain a more accurate understanding of how geopolitical configurations affect violence simply by integrating the many specific micro relationships into a coherent macro whole.

I build on Bernholz (1985) to create a unifying framework to study the net effects of a 'monopoly of violence within a geographic territory'. First, I extend the cost/benefit model of state size (Friedman 1977; Wittman 1991; Alesina and Spolaore 1997, 2003, 2005) to incorporate the spatial aspects of conflict at the micro level (Caselli et al. 2015; Spolaore 2016; Adamson and Kimbrough 2019). In the model, the amount of violence at any location depends on the entire size distribution of states in the area, which captures many important relationships: e.g., how the costs of conflict for a militia on the periphery are affected by how easy it is to cross borders, how much they are surveilled, and the ability to evade an arms blockade along a nearby transportation route. ${ }^{4}$ Then, following the many scholars who use a concentration index because of its statistical properties (Hirschman 1945; Mansfield 1993; Abramson 2017), I build on Levy and Markowitz (1979) to derive the Herfindahl-Hirschman Index of state sizes as a second-order approximation of a general and unknown relationship. In doing so, I show that the many micro effects of partitioning a region into many small countries (e.g., more external and less internal conflict) can be approximated by the effect of geopolitical concentration.

This unifying framework helps bring the spatial patterns of conflict in Africa to bear on the classical questions about optimal political geography (Bernholz 1985; Alesina and Spolaore 1997). The evidence from Africa is not perfect, but it improves upon the historical association of smaller and weaker states with more violence (Gat 2006; Pinker 2012; Morris 2014). ${ }^{5}$ Besides the difficulty in comparing small samples in different periods, it is hard to establish causality when country numbers/sizes are determined by violent conflicts or third factors that affect both violence and country numbers/sizes. In contrast, Africa provides empirical evidence where the borders were externally determined by the colonial powers of Europe. This means that historical borders were not determined by the recent violence, and that unobserved factors are less likely to have determined both the historical borders and the recent violence. And by using geocells as my unit of observation, rather

\footnotetext{
${ }^{2}$ A largely forgotten and a-theoretical literature had documented that there is a correlation between internal and external conflicts when comparing countries using factor analysis (Tanter 1966; Wilkenfeld 1968; Eberwein et al. 1979).

3 Moreover, it was often the same individuals fighting. For example, Paul Kagame first fought in Uganda's coup before leading the Rwanda coup and ultimately supporting the coup in the Democratic Republic of the Congo. More generally, Bernholz (1985, The Means of Foreign Policy) discusses multiple other ways foreign countries have meddled with their neighbors' internal tensions.

4 Similarly, the model captures how a national army patrolling a larger number of locations would have to cover more distance to reinforce any other location. For Africa in particular, many of the political capitals were placed in the center of the region to ease strategic military operations around the country (e.g., Addis Ababa), and the distance to one or all political capitals is a function of all geographic state sizes.

5 In particular, I improve on Richardson (1960) whose data on war, civil war, and border lengths suggested that "that the unification of a number of independent organizational entities (states) into one nation reduces the amount of violence in that region" (Bernholz 1985).
} 
than states, ethnicities, or other political units, I can systematically observe how geopolitical concentration affects all types of conflict in an area.

As such, both the theory and evidence provided in this paper informs the debate about fragmentation and growth over the longue durée. Some historical scholars have argued the external conflicts in Europe caused political fragmentation and state-capacity that ultimately improved the economy (e.g., Dincecco and Prado 2012; Voigtländer and Voth 2013). Yet, in Africa, the wars have not reproduced the theorized relationship between war, state-capacity, and development. ${ }^{6}$ Perhaps this is not surprising, as a more encompassing state is a double-edged sword; making it easier for the government to provide for the common good (e.g., supporting markets as in Besley and Persson (2014)) but also to persecute and plunder (e.g., extracting rents as in Hillman (2005)). Although political fragmentation is associated with external conflict, other have argued it increased policy innovation (Bernholz et al. 1998), competition to attract citizens/capital (Karayalçin 2008), and cultural innovation (Bernholz 1985; Derex et al. 2018). By contrasting Europe's many smaller states to China, Ko et al. (2018) even argued that fragmentation improved mideival defenses to external threats. But in addition to these benefits of fragmentation, making huge states smaller might directly reduce the amount of internal violence-perhaps outweighing increases in external violence (conceptualized here as a cost). ${ }^{7}$

Conversely, this paper also contributes to the literature examining the legacy of colonization in Africa and poor outcomes today (Nunn 2008). For example, Nunn and Wantchekon (2011) analyzed how slavery as much as 600 years ago has adversely affected the "factors that are internal to the individual, such as cultural norms, beliefs, and values" and Michalopoulos and Papaioannou (2016) analyzed the partition of historical ethnic regions. I differ by analyzing how fighting is mitigated or exacerbated by the imposed geopolitical factors that are still in play. It would be surprising if the geopolitics discussed by Bernholz (1985) — crucial to military considerations in many other regional and historical settingwould not matter for conflict in Africa. Such considerations may even interface economic motives with the internal and ethnical factors that other scholars have emphasized: when resources are highly concentrated in the political sphere, ethnic differences are seen as a way to organize interests in a competitive struggle over resources rather than as a source of comparative advantage. By contrast, "In the market place they [Sudanese tribes] provide complementary goods: the Baggara supply milk and livestock, and the Fur supply agricultural products of which millet is of major importance to the Baggara" (Haaland 1969, p. 59). ${ }^{8}$ While many factors affect conflict in Africa, this paper contributes by systematically

\footnotetext{
${ }^{6}$ Many technological and commercial factors are missing, which other scholars have argued are responsible for both violence and political development (e.g., North 1982; Boix 2015; Abramson 2017). Centeno (2002) also argued the link between war and growth does not replicate in Latin America and discusses the importance of both internal and external conflict.

7 As evident in my epigram, I also draw from mideival of Europe. But the essential internal/external tension that I highlight appears to extend to much earlier periods of Europe as well: "the property of the state should not be so large that more powerful neighbors may be tempted by it ... nor yet so small that the state is unable to maintain a war" Aristotle (350 B.C. [1885]).

${ }^{8}$ Recent econometric findings in Europe also emphasize the power of the market in conceptualizing ethnic differences (Anderson et al. 2016; Hornung 2019), and Caselli and Coleman (2013) theorized that "economic development alone will remove the incentives for ethnic conflict, particularly if it is accompanied, as it often is, by a structural transformation." Africa is not an exception, as the Human Rights Watch (2008, p. 138) reports that "many Nigerians believe the government's failure to combat the nation's grinding poverty lies at the heart of many conflicts that appear to be ethnic or religious in nature, as competition for scarce economic resources becomes increasingly desperate."
} 

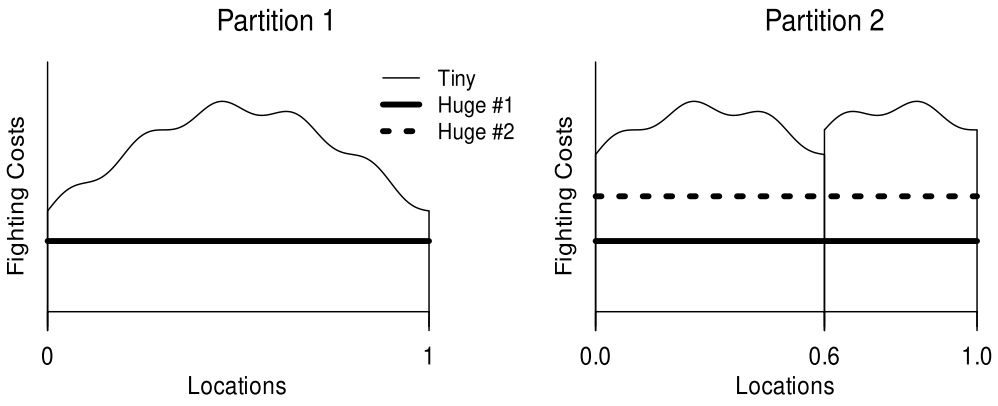

Fig. 1 Hypothetical cost distributions

analyzing whether the geopolitical considerations emphasized by Bernholz (1985) are also important.

I empirically analyze violence and the geopolitical concentration of countries in Africa over a period spanning 1989-2014, and the findings are fundamental. On average, there is more violence when there are many small countries in an area and less violence when there is one large country in an area. However, violence decreases at a diminishing rate and begins to increase near monopoly values (along the lines of my epigram from Montesquieu). These findings are present in both the raw data and when controlling for other factors. As a whole, these empirical results suggest that partitioning affects multiple types of contestants, that the importance of any particular type of violence depends on the spatial context, and that there is a non-monotone effect of concentration on violence in the aggregate.

\section{Theory}

Two types of players compete for resources at locations on a line: tiny location-specific players (representing individuals) that only compete at their location, and huge players (representing national governments) that partition the line into segments and compete at all locations. Both types of players compete for resources by expending effort to increase their share of a resource at each location, which is also interpreted as increasing their probability of winning the resource (Tullock 1974). All players incur a constant marginal cost of effort, but those costs are specific to each location (and where that location sits geopolitically). For example, tiny players have an inverse-U shape within their segment because it is easier to organize rebellion on the periphery where the central government is more absent. Huge players could also have costs that vary over space (i.e., higher costs away from a capital) but I hold these constant for exposition. All players simultaneously choose how much effort to expend, and the resource share ultimately obtained by each player at each location (probability of winning the resources) are equilibrium outcomes shaped by the geopolitical configuration. Players with lower fighting costs end up with larger resource shares (i.e., more powerful countries have higher probabilities of winning).

Figure 1 illustrates how different partitions change the number of contestants (and their costs of fighting) at each location within a unit interval. Thin lines represent the costs for tiny players, and thick lines represent the costs of huge players. The first partition shows the costs of conflict when one huge player controls the entire segment. The second partition 
shows the costs of conflict when one huge player controls $60 \%$ of the segment, and another huge player controls the remaining $40 \%$ of the segment (costs of the second huge player are shown as a dashed line). The total amount of conflict effort at a location is increasing with the number of contestants but decreasing with the average cost of effort. This particular example shows there are competing effects when partitioning an area into many small countries; more external actors (increasing fighting) and higher costs of fighting for internal actors (decreasing fighting).

A central feature of my model is that countries are not single homogenous actors, rather they comprise a national government as well as a large number of local actors each pursuing their own goals. This means that having a single huge player in a region is a political monopoly, but not necessarily a monopoly on violence. Crucially, a political monopoly only leads to less conflict effort overall if the increase in the average cost of conflict across all contestants is higher.

This model focuses on which geopolitical configurations mitigate or exacerbate conflict, and takes as given the multitude of motivations for why people fight (e.g., religion, ethnicity, historical brutality, etc.) as well as the multitude of alternative political arrangements. Yet, the cost/benefit structure of the model does allow for many other factors to be incorporated alongside the spatial factors, which play a central role in the location of conflict. For example, holding the geopolitical configuration fixed, increasing the heterogeneity of the population would lower the costs of tiny players fighting (what Alesina and Spolaore call "heterogeneity costs"). Another example, when a government becomes tyrannical there are lower costs to tiny players fighting which leads to more rebellion on the periphery and more suppression in the capital (where the costs of fighting are more favorable to tiny or huge players). This examples alone suggest that the spatial distribution of countries affects the locations of 'internal conflict', even before incorporating how geopolitical configurations affect external spillovers (proxy wars between states) or internal reactions (whether ethnic groups move or solidify with strict boundaries).

\subsection{Spatial model of conflict}

There are a large but finite number of locations located on the line $(0,1]$. There are $N \geq 1$ huge players that partition the line into segments $\left\{\left(0, S^{1}\right], \ldots\left(S^{N-1}, 1\right]\right\}$, and a tiny player at each location. Each location $\ell$ in has resources $R_{\ell} \geq 0$, where the $N$ huge players and the 1 tiny player compete for shares of the resource. Each player $i$ competes by putting forth fighting effort $e_{\ell}^{i}$ to obtain a resource share $s_{\ell}^{i} \in[0,1]$. Assume all players expend positive fighting effort and the resource shares are determined by the Tullock contest success function; $s_{\ell}^{i}=e_{\ell}^{i} / E_{\ell}$, where

$$
E_{\ell}=\sum_{j}^{N+1} e_{\ell}^{j}
$$

is the the sum of all efforts. Each player at each location has a constant marginal cost of fighting effort, $c_{\ell}^{i}>0$, and earns profit

$$
\Pi_{\ell}^{i}=R_{\ell} \frac{e_{\ell}^{i}}{E_{\ell}}-c_{\ell}^{i} e_{\ell}^{i} .
$$


Tiny players optimize at only their location, while huge players optimize over all locations; $\sum_{\ell} \Pi_{\ell}^{i}$. Taking others' fighting efforts are taken as given, the first order condition for player $i$ at location $\ell$ is

$$
\begin{aligned}
{\left[\frac{1}{E_{\ell}}-\frac{e_{\ell}^{i}}{\left(E_{\ell}\right)^{2}}\right] R_{\ell} } & =c_{\ell}^{i} \\
e_{\ell}^{i} & =E_{\ell}-c_{\ell}^{i} \frac{\left(E_{\ell}\right)^{2}}{R_{\ell}} .
\end{aligned}
$$

By substituting Eq. 3 back into Eq. 1, we find total amount of fighting effort in Nash Equilibrium;

$$
\begin{aligned}
& E_{\ell}=(N+1) E_{\ell}-\frac{\left(E_{\ell}\right)^{2}}{R_{\ell}} \sum_{j}^{N+1} c_{\ell}^{j} \\
& E_{\ell}^{*}=\frac{N R_{\ell}}{\sum_{j}^{N+1} c_{\ell}^{j}}=\frac{N}{N+1} \frac{R_{\ell}}{\bar{c}_{\ell}},
\end{aligned}
$$

where $\bar{c}_{\ell}=\frac{1}{N+1} \sum_{j} c_{\ell}^{j}$ is the across-player average marginal costs of fighting effort at location $\ell$. From this, we find the total amount of fighting effort from all players over all locations

$$
\sum_{\ell} E_{\ell}^{*}=\frac{N}{N+1} \sum_{i} \sum_{\ell>S^{i}}^{S^{i+1}} \frac{R_{\ell}}{\bar{c}_{\ell}},
$$

where $\sum_{\ell>S^{i}}^{S^{i+1}} R_{\ell} / \bar{c}_{\ell}$ is the total amount of conflict within the borders of country $i$, who has a total size of $s^{i}=S^{i+1}-S^{i}$. Equation 5 shows the total amount of fighting effort depends on the number of countries, $N$, the spatial configuration of countries, $\left\{\left(S^{i}, S^{i+1}\right]\right\}_{i}$, and the ratio of benefits and costs of conflict at each location, $R_{\ell} / \bar{c}_{\ell}$. In "Appendix" section "The contingent effects of concentration", I make some simplifying assumptions to provide an analytic example of how the overall amount of violence relates ambigiously to Herfindahl-Hirschman Index because of heterogeneous effects on different actors. But in the remaining theory and empirics, I assume the per-location costs and benefits of conflict depend generally on the sizes of all states surrounding a location; $R_{\ell} / \bar{c}_{\ell}=V\left(s_{\ell}^{1}, s_{\ell}^{2}, \ldots\right)$, and use the Herfindahl-Hirschman Index as a summary statistic for the general relationship.

\subsection{State sizes and the Herfindahl-Hirschman index}

In this section, I show that a relationship between violence and the size distribution of states has an approximately local-linear relationship with a Herfindahl-Hirschman Index $(H H I)$ of state sizes. Specifically, this is the result of a second order Taylor-approximation of $V\left(s^{1}, s^{2}, \ldots\right)$ around sizes $(a, a, \ldots) ; V\left(s^{1}, s^{2}, \ldots\right) \approx$

$$
V(a, a, \ldots)+\sum_{i}^{N} V_{i}(a, a, \ldots)\left(s^{i}-a\right)+\frac{1}{2} \sum_{i}^{N} \sum_{j}^{N} V_{i j}(a, a, \ldots)\left(s^{i}-a\right)\left(s^{j}-a\right) .
$$

Note the sum of all country sizes equals the length of the line, $\sum_{i} s^{i}=1$, and this bounds the geopolitical concentration index, $H H I=\sum_{i}^{N}\left(s^{i}\right)^{2} \in[0,1]$. For all states around 
the approximation $a=1 / N$, assume the first and second derivatives $\left(V_{i}\right.$ and $\left.V_{i i}, V_{i j}\right)$ are the same for all $i, j$. Note that $\sum_{i}^{N}\left(s^{i}-a\right)=0$, and $\sum_{j \neq i}^{N}\left(s^{j}-a\right)=-\left(s^{i}-1 / N\right)$, and $\sum_{i}^{N}\left(s^{i}\right)^{2}=\sum_{i}^{N}\left(s^{i}-1 / N\right)^{2}+1 / N$. Then rewrite Eq. 6 as

$$
V\left(\frac{1}{N}, \frac{1}{N} \ldots\right)+\frac{V_{i i}\left(\frac{1}{N}, \frac{1}{N} \ldots\right)}{2} \sum_{i}^{N}\left(s^{i}-\frac{1}{N}\right)^{2}-\frac{V_{i j}\left(\frac{1}{N}, \frac{1}{N} \ldots\right)}{2} \sum_{i}^{N}\left(s^{i}-\frac{1}{N}\right)^{2} .
$$

After gathering like terms, Eq. 8 shows violence is an approximately linear function of the $H H I$. The linear approximation is justified locally but can be evaluated at $H H I=1 / N$ to collapse the sizes and numbers of countries along a single dimension';

$$
V\left(s^{1}, s^{2}, \ldots\right) \approx A(H H I=1 / N)+B(H H I=1 / N) \times H H I,
$$

where $B$ and $A$ are slope and intercept terms. This implies the overall amount violence in Eq. 5 can be approximated by

$$
\frac{N}{N+1} \sum_{i} \sum_{\ell>S^{i}}^{S^{i+1}}\left[A_{\ell}+B_{\ell} H H I_{\ell}\right]
$$

In contrast with other measures that result from specific models about one type of conflict with one specific mechanism, this model approximates the overall amount of violence at each location (and in the entire region) with the $H H I$ of country sizes. ${ }^{10}$ However, the approximation does not specify the direction or magnitude of the effects (the slope and intercept terms are not known apriori) and is only justified locally. The effect of geopolitical concentration on violence will be different for areas with many small countries and areas with a single large country, but this can be estimated empirically.

\section{Empirics}

To arrest the fighting in Africa, political unity has often been the prescription. Many scholars observe the recent fighting and conclude the state is too weak and a political monopoly increases welfare (De La Sierra 2017). Yet, the history of Africa is replete with totalitarian governance and bad results. A lack of state-capacity was not the problem, and perhaps nowhere are the simultaneous geopolitical concerns about foreign invasions, secessionist movements, and internal rebellions more clear than in the Democratic Republic of Congo (Nest et al. 2006; Stearns 2012; Van Reybrouck 2014; Kisangani 2016).

While individuals in the Congo had historically been organized by ethnic groups that were 'fluid and intermixed' (Christensen and Laitin 2019) the now Democratic Republic

\footnotetext{
9 This matches Hirschman's original motivation in for constructing the index in National power and the structure of foreign trade (1945); "the two conditions which any index of our concept of concentration should meet are fully realized by the measure here proposed: It increases with the relative dispersion $v$ and decreases with the number $N$ of the elements of the series."

10 For instance, the size distribution of countries could affect the bargaining power and support for different parties at any location. The size distribution of countries could also affect the trading relationships amongst different parties. Changing the geopolitical situation will change many micro relationships, and the $H H I$ is just a way to summarize and aggregate the multiple effects.
} 
of Congo was granted to Belgium at the Berlin Conference. ${ }^{11}$ A central impetus for the state was that a large Congo ruled by a small Belgium would serve as a strategic buffer in Africa. But, after years of often brutal colonial rule, the DRC became an independent state in 1960. The region Congo-Stanleyville rebelled and the region Katanga seceded shortly afterward. (These separatist regions do not at all line up with the ethnic boundaries or partitions that political-economists have pointed to.) Then, with the help of foreign intervention, these regions were reincorporated to recreate the original boundaries. In 1965, Mobutu Sese Seko launched a successful coup d'état, and his totalitarian regime began to homogenize the population and command the economy in a program of 'Zairianization'. The results were disastrous. Katanga again rebelled in the late 1970s, but was again corralled with the help of international forces. Tensions would ultimately boil over in the Great African Wars.

In the decades after the Katanga's failed secession, in the Congo region and elsewhere in Africa, there were many conflicts with different national governments and sub-national militias all taking part. In the early 1990s, popular insurrections emerged in the DRC with international backing on multiple sides. In 1997, Laurent-Désiré Kabila (originally from Katanga and former secessionist leader in Kivu), overthrew Mobutu with support from Uganda, Rwanda, and Burundi. Kabila then ruled the country as an authoritarian, broke ties with his former backers, and was assassinated four years later. His son, Joseph Kabila, was sworn in as the new leader in 2001 and ruled a war-torn country (with internal rebels and meddling neighbors) until 2019. The Great African Wars of the 1990s enveloped the $\mathrm{DRC}$, and it is during and after these wars where the econometric study takes place.

\subsection{African borders and geopolitical concentration}

In Africa, it is widely argued that the colonial powers drew borders without regard for the local inhabitants in an arbitrary way (Michalopoulos and Papaioannou 2016). For example, Ahmad, M. (African Union Border Programme 2014) says the "realities on the ground and testimonies from the key actors at the time when the boundaries were being designed and constructed, conclusively confirm that the borders are indeed arbitrary and artificial" and many point to the admission by the contemporary British Prime Minister that

We have been engaged in drawing lines upon maps where no white man's foot ever trod: we have been giving away mountains and rivers and lakes to each other, only hindered by the small impediment that we never knew exactly where the mountains and rivers and lakes were. - Lord Salisbury (quoted from African Union Border Programme 2014, p. 13)

While the colonial powers have changed borders since the Berlin conference, they have remained remarkably stable as a whole. The WWI allies divided German East Africa amongst themselves, for example, but the majority of borders since African independence have remained frozen with what the colonizers had chosen. Today, Alesina et al. (2011) estimated that "eighty percent of African borders follow latitudinal and longitudinal lines".

11 Meditz and Merrill (1994) report that "Calculations of the number and relative sizes of ethnic groups in Zaire are at best approximations, however. These groups are neither fixed entities nor the sole or even primary points of reference for all Zairians". The 250 Congolese ethnicities sometimes reported corresponds neatly with the fact that "Leopold was able to produce more than 250 treaties signed in his name" (Kisangani 2016). 
Fig. 2 HHI calculation

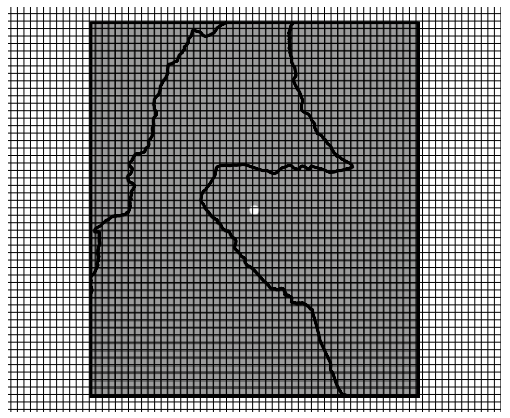

No political geography is completely exogenous, but the African borders (from the perspective of the inhabitants) have a much bigger random component than elsewhere. This is important because all locations in a region can be affected by the geographic concentration of countries-making many empirical strategies unsuitable. (For example, the stable unit treatment values assumption used in spatial regression-discontinuities would be violated.) The best chance to understand the causal effect of geopolitical concentration is from a natural experiment where all or most of the borders over a large region were imposed. Thus, I examine Africa. However, there could still be non-random differences across regions with many smaller countries or fewer larger ones. To address this concern, the econometric analysis also controls for a variety of other factors that could be correlated with the country sizes and affect the estimated relationship between geopolitical concentration and conflict. But first I describe how I use the borders of African countries to calculate geopolitical concentration.

Using political maps from Weidmann and Gleditsch (2010), I calculate the Herfindahl-Hirschman Index $(H H I)$ of African countries, what I term geopolitical concentration, in close accordance with the theory. To do so, I construct a grid by dividing the map of Africa into a $1000 \times 1000$ grid of equal-area geocells $(7101 \mathrm{~m} \times 8876 \mathrm{~m}, \approx$ size of a small US county) using the Mollweide projection. I drop all geocells that are only ocean, which leaves 476743 geocell. For each geocell, I construct a square geographic window (with diameter $w$ ) that contains a land area for each country $s^{i}(w)$ and total area $s(w)$. I then calculate a geocell's Herfindahl-Hirschman Index as

$$
H H I(w)=\sum_{i}\left(\frac{s^{i}(w)}{s(w)}\right)^{2} .
$$

Note that $H H I \in[0,1]$, where closer to 0 indicates many smaller countries and closer to 1 indicates fewer larger countries. Consider one specific example of the calculation in Fig. 2. I take a geocell (represented as a white dot) and construct a $50 \times 50$ window around it (represented as a grey square). I then calculate the areas of the countries in that window, which are Nigeria (0.1), Cameroon (0.48), and Chad (0.42), in order from left to right. Finally, I calculate the $H H I$ value of those shares, which is 0.4 in this instance.

The fine grid size allows the violence versus $H H I$ relationship to be evaluated for many locations (as in the theory), while the window size determines the scale of analysis. Separating windows from geocells allows me to separately analyze larger scales without discarding local information. I use a $50 \times 50$ window $\left(\approx 160,000 \mathrm{~km}^{2}\right.$ or the size of Washington State) for the baseline and examine different window sizes for robustness. For the baseline window, the mean $H H I=0.76$ and median $H H I=0.79$, which both decrease 
Table 1 Definition of political violence

\begin{tabular}{|c|c|c|}
\hline Source & Years & Definition \\
\hline ACLED & 1997-2014 & $\begin{array}{l}\text { Activity that occurs within the } \\
\text { context of a civil war, and violent } \\
\text { activity that occurs outside of } \\
\text { civil wars, particularly violence } \\
\text { against civilians, militia interac- } \\
\text { tions, communal conflict and } \\
\text { rioting }\end{array}$ \\
\hline UCDP & 1989-2014 & $\begin{array}{l}\text { Contested incompatibility that } \\
\text { concerns government and/or terri- } \\
\text { tory, where the use of armed force } \\
\text { between two parties, of which at } \\
\text { least one is the government of } \\
\text { a state }\end{array}$ \\
\hline
\end{tabular}

when examining larger window sizes. While the analysis could be generalized to any size region, the most immediate neighbors are the most important conflict considerations (as noted by Bernholz 1985).

\subsection{Political violence and geopolitical concentration}

The number of fatalities resulting from armed political conflict in modern Africa is measured by two institutes, the Armed Conflict Location and Event Data (ACLED, Raleigh et al. 2010) and the Uppsala Conflict Data Program (UCDP, Sundberg and Melander 2013). Each dataset provides disaggregated about the type and location of fatalities across the entire continent. Table 1 shows the general definitions of violence given by each data set, of which I use fatalities. I use two datasets to mitigate reporting spurious results particular to either dataset.

I also use two datasets because their different orientions allow me to measure differential changes in internal versus external conflicts. Strict separations of internal and external conflict would be difficult in the history the DRC (i.e., Laurent Kabila's coup and the links with Rwanda seem to encapsulate both), and it is also difficult to do in the ACLED and the UCDP datasets. ${ }^{12}$ For example, in addition to the definitions included in Table 1, ACLED also notes there are different foreign groups active in a state's territory. Similarly, the UCDP definition of conflict also includes fighting between state and non-state actors outside of the state, as well as fighting within the state under foreign support. So the conflicts in both datasets are the result of multiple different types of actors fighting, but ACLED is more internally focused. Figure 3 plots the fatalities from both datasets over all years as points over top of the 2015 political boundaries (darker areas represent higher intensity). ${ }^{13}$

The conflict data are aggregated into geocells, using the same grid used to construct the $H H I$, and then averaged over time. I log transform the conflict data to make the

\footnotetext{
12 While some scholars have classified ACLED as internal-ethnic conflicts, many rebel groups comprise multiple ethnicities from other countries-some of which have entirely switched sides (Seymour 2014).

13 Each overlapping point is semi-transparent and has a size that represents the number of deaths. The map is horizontally stretched for visual representation.
} 
Fig. 3 Map of countries and violence
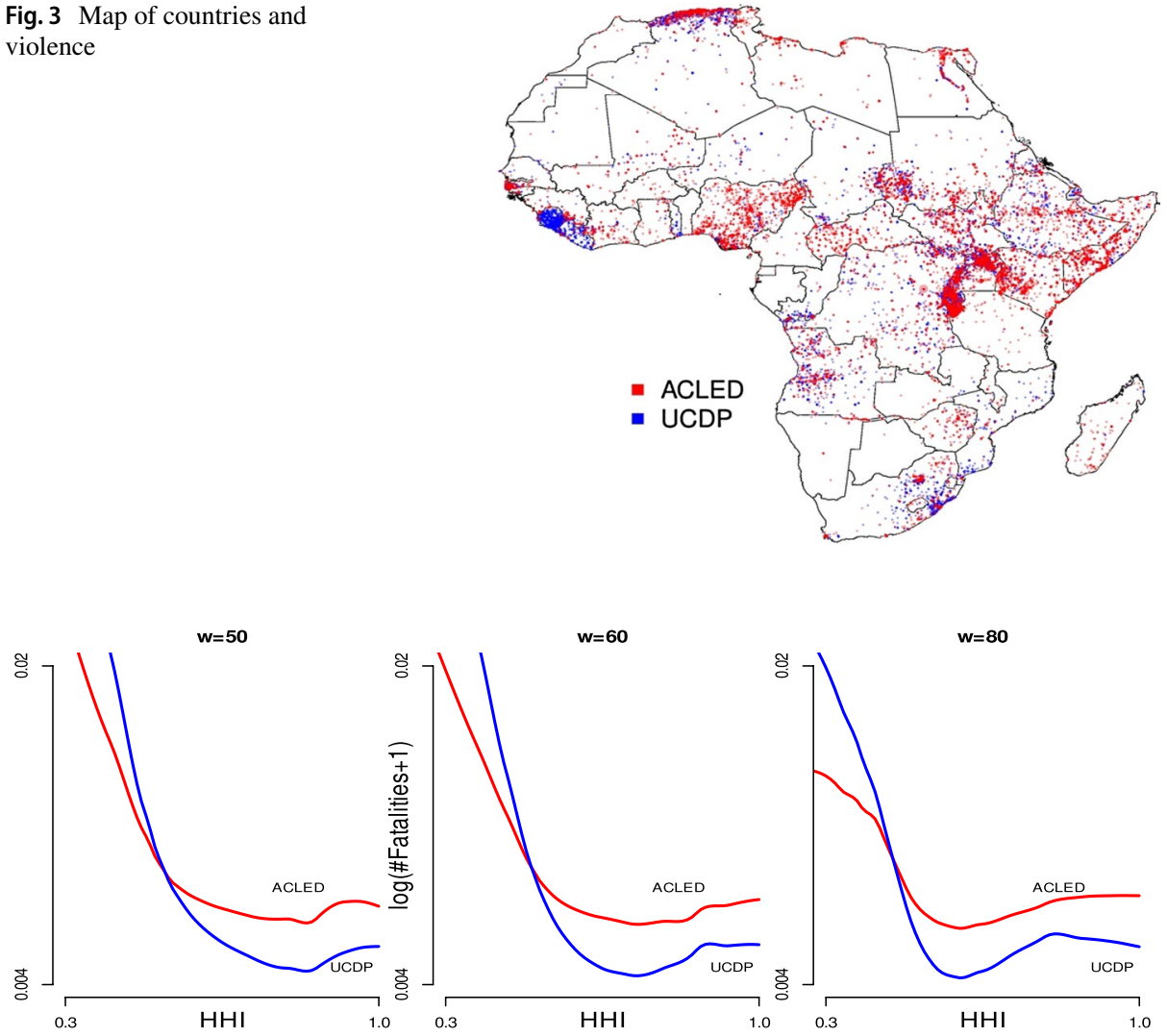

Fig. 4 Violence versus geopolitical concentration

results from both datasets comparable (with the marginal effects of covariates interpreted as partial elasticities). I then analyze the raw bivariate relationship between violence and geopolitical concentration with a local linear regression of violence on geopolitical concentration. For each geocell $g$, I use the loess smoothing function (with weighting parameter .5) for window sizes $w \in\{50,60,80\}$. I plot the results for both datasets in Fig. 4. The level of violence is high in areas with low concentration and is low in areas with high concentration. But the trend is non-monotonic; violence diminishes with concentration at a decreasing rate and reverses as an area becomes highly concentrated. The raw data suggest a quadratic relationship with a minimum amount of violence at $H H I$ inside of $(0,1)$. The reversal happens at lower values for $w=80 \mathrm{com}$ pared to $w=50$, which suggests geopolitical monopolization over larger regions is associated with larger increases in conflict. Moreover, these patterns are driven by changes in behavior, as simply recoding external/internal fighters would lead to no pattern (a horizontal line). Moreover, when comparing ACLED to UCDP data sets, the data set more associated with civil conflict (ACLED) reports higher values for $H H I>.8$ and lower values for $H H I<.4$. This suggests geopolitical monopolization is associated with increases in civil conflict. 
Table 2 Control variables

\begin{tabular}{|c|c|}
\hline Variable & Description \\
\hline Diamond & $\begin{array}{l}\text { Number of diamond mines within a geocell. My calculation using data from Gilmore et al. } \\
\text { (2005) }\end{array}$ \\
\hline OilGas & $\begin{array}{l}\text { Number of oil and gas fields within a geocell. My calculation using data from Lujala et al. } \\
\text { (2007) }\end{array}$ \\
\hline Precip & Average precipitation within a geocell. Data from Hijmans et al. (2005) \\
\hline CoastDist & $\begin{array}{l}\text { Distance from geocell centroid to the Coast. My calculation using data from Weidmann } \\
\text { and Gleditsch (2010) }\end{array}$ \\
\hline Ruggedness & Terrain Ruggedness Index (FAO et al. 2012 elevation data) \\
\hline CapitalDist & $\begin{array}{l}\text { Distance from cell centroid to nearest national capital. My calculation using data from } \\
\text { Weidmann and Gleditsch (2010) }\end{array}$ \\
\hline HHI(ethnic) & $H H I$ of ethnic regions. My calculation using data from Murdocks Map (1959) \\
\hline BorderDist & $\begin{array}{l}\text { Distance between a geocell to the nearest border. My calculation using data from Wei- } \\
\text { dmann and Gleditsch (2010) }\end{array}$ \\
\hline Pop & $\begin{array}{l}\text { Population count. Data from CIESIN (2005) for years 1990, 1995, 2000; Linard et al. } \\
\text { (2012) for years 2000, 2005, 2010, } 2015\end{array}$ \\
\hline Lights & $\begin{array}{l}\text { Night-time lights. Data from NOAA/NGDC for years 1992-2003 from the United Nations } \\
\text { Environment Programme }\end{array}$ \\
\hline Lake & $\begin{array}{l}\text { Share of geocell area covered by Lake. My calculations using water data from the Regional } \\
\text { Centre for Mapping of Resources for Development }\end{array}$ \\
\hline Slaves & $\begin{array}{l}\text { Historical slave exports per area. Slave data for ethnic regions calculated by Nunn and } \\
\text { Wantchekon (2011) }\end{array}$ \\
\hline Sahara & Indicator if cell is above $15^{\circ}$ latitude. My calculations \\
\hline Religion & $\begin{array}{l}\text { Indicates most common religion (Christian, Muslim, or Tribal) in 2008. Data from the } \\
\text { Harvard Worldmap sourced from the World Religion Database }\end{array}$ \\
\hline British, French & $\begin{array}{l}\text { Indicators for whether original colonizer was British or French. Data from de Sousa and } \\
\text { Lochard (2012) }\end{array}$ \\
\hline
\end{tabular}

\subsection{Overall violence and $\mathrm{HHI}$, controlling for other factors}

To control for other geographic and political factors, I compile a cross-sectional dataset. I do this by aggregating the data into geocells and then averaging over time. By projecting the geographic data onto equal-area cells before aggregation, I eliminate the bias stemming from heterogeneous cell sizes. This is particularly important for dealing with violence data because cell size affects per-cell counts and per-cell probabilities of observing events. ${ }^{14}$ There are two groups of control variables: Demographic/Geographic Dem. + Geo. $=[$ LightsPop, Diamond, OilGas, Precip, CoastDist, Ruggedness, Lake, Sahara], and Political/Ethnic Pol + Ethnic $=[$ CapitalDist, BorderDist, British, French, HHI(Ethnic), Slaves, Religion $]$. The exact definitions and sources are given in Table 2. This list of controls is not exhaustive, but it allows me to control for the major factors emphasized in the literature (e.g., ethnic compositions, border distances, natural resources, etc.).

I use a multivariate OLS model (with the quadratic form suggested by the raw data) to examine how the level of violence changes with geopolitical concentration when

\footnotetext{
${ }^{14}$ For example, the number of mines per cell, a weather anomalies indicator, and the population count would all be severely affected by projections that do not preserve area.
} 
Table 3 Geopolitical concentration and overall violence

\begin{tabular}{lllllll}
\hline & ACLED & UCDP & ACLED & UCDP & ACLED & UCDP \\
\hline HHI & $-3.15^{* *}$ & $-3.80^{* * *}$ & $-3.20^{* *}$ & $-3.95^{* * *}$ & $-1.12^{* *}$ & $-1.57 * * *$ \\
& $(1.30)$ & $(1.15)$ & $(1.27)$ & $(1.13)$ & $(0.47)$ & $(0.45)$ \\
$\mathrm{HHI}^{2}$ & $1.98^{* *}$ & $2.41^{* * *}$ & $1.97 * *$ & $2.53 * * *$ & $0.65^{* *}$ & $1.01^{* * *}$ \\
& $(0.85)$ & $(0.75)$ & $(0.83)$ & $(0.74)$ & $(0.33)$ & $(0.31)$ \\
ArgMin & 0.79 & 0.79 & 0.81 & 0.78 & 0.86 & 0.78 \\
Dem. + geo. & $\mathrm{Y}$ & $\mathrm{Y}$ & $\mathrm{Y}$ & $\mathrm{Y}$ & $\mathrm{Y}$ & $\mathrm{Y}$ \\
Pol. + ethnic & $\mathrm{N}$ & $\mathrm{N}$ & $\mathrm{Y}$ & $\mathrm{Y}$ & $Y^{\mathrm{a}}$ & $Y^{\mathrm{a}}$ \\
Country F.E. & $\mathrm{N}$ & $\mathrm{N}$ & $\mathrm{N}$ & $\mathrm{N}$ & $\mathrm{Y}$ & $\mathrm{Y}$ \\
Observations & 476,743 & 476,743 & 476,743 & 476,743 & 476,743 & 476,743 \\
\hline
\end{tabular}

The dependant variable is $\log (\#$ Fatalities +1$)$. Also included in some regressions are Demographic + Geographic controls, Political + Ethnic controls, or country fixed effects. Colonizer fixed effects are excluded when country fixed effects are included (denoted as $\mathrm{Y}^{\mathrm{a}}$ in the table). Spatial HAC standard errors reported. Coefficients and Standard Errors multiplied by 100 for reporting

$* p<0.1 ; * * p<0.05 ; * * * p<0.01$

controlling for other factors. Specifically, the unit of observation is geocell $g$, and I examine how the number of fatalities changes with $\operatorname{HHI}(w=50)$ when including other Controls;

$$
\log (\# \text { Fatalities }+1)_{g}=H H I_{g} \beta_{1}+H H I_{g}^{2} \beta_{2}+\text { Controls }_{g} \gamma+\epsilon_{g} .
$$

The standard errors in the baseline model are corrected post-estimation for spatial dependence (spatial HAC), and some specifications also include fixed effects for which country ID each geocell's centroid falls on. ${ }^{15}$ This statistical model allows me to control for confounding country-specific factors as well as spatial autocorrelation. Note that if country fixed-effects are included, then the fixed effects for British and French colonizer are not. In "Appendix" section "Further results on functional form", I analyze non-logarithmic Heckit models, generalized additive models, and other semi-parametric models to examine further non-linearities.

Table 3 reports the regression estimates using different sets of controls. The overall finding is that geocells in unconcentrated areas have more violence than geocells in concentrated areas, but geocells in highly concentrated areas have more violence than moderately concentrated ones. Columns 1 and 2 show the main result when holding demographic and geographic factors constant. The interpretation of columns 3 and 4 is similar to columns 1 and 2, but also holds other political and ethnic factors constant. Columns 5 and 6 show the main result when comparing geocells within the same country and holding the other observable factors constant. The row ArgMin shows the predicted values of $\mathrm{HHI}$ that minimize violence. Similar to the relationship found in the raw data, violence is at first decreasing, but then increasing, and is minimized at $H H I<1 .{ }^{16}$ The interested reader is directed to Table 5 to see all coefficient estimates and some further discussion.

\footnotetext{
15 The spatial HAC down weights nearby observations using a Bartlett kernel up to a cutoff of about $90 \mathrm{~km}$.

16 Note that the predicted ArgMins are close to the mean and median values of HHI. This suggests that the increase in violence associated with high amounts of geopolitical concentration is directly relevant to many African regions.
} 
Table 4 Geopolitical concentration and violence by window extent

\begin{tabular}{lllllll}
\hline & ACLED & ACLED & ACLED & UCDP & UCDP & UCDP \\
\hline HHI(50) & $-1.12^{* *}$ & & & $-1.57^{* * * *}$ & & \\
& $(0.47)$ & & & $(0.45)$ & & \\
HHI(50) $)^{2}$ & $0.65^{* *}$ & & & $1.01^{* * *}$ & & \\
& $(0.33)$ & & & $(0.31)$ & & \\
HHI(60) & & $-1.13^{* * *}$ & & & $-1.40^{* * * *}$ & \\
& & $(0.39)$ & & & $(0.36)$ & \\
HHI(60) & & $0.70^{* *}$ & & & $0.90^{* * * *}$ & \\
& & $(0.29)$ & & & $(0.26)$ & \\
HHI(80) & & & $-0.89^{* * *}$ & & & $-0.91^{* * *}$ \\
& & & $(0.35)$ & & & $(0.31)$ \\
HHI(80) & & & $0.61^{* *}$ & & & $0.57 * *$ \\
& & & $(0.27)$ & & & $0.23)$ \\
ArgMin & 0.86 & 0.81 & 0.73 & 0.78 & 0.78 & 0.8 \\
Dem. + geo. & $\mathrm{Y}$ & $\mathrm{Y}$ & $\mathrm{Y}$ & $\mathrm{Y}$ & $\mathrm{Y}$ & $\mathrm{Y}$ \\
Pol. + ethnic & $\mathrm{Y}$ & $\mathrm{Y}$ & $\mathrm{Y}$ & $\mathrm{Y}$ & $\mathrm{Y}$ & $\mathrm{Y}$ \\
Country F.E. & $\mathrm{Y}$ & $\mathrm{Y}$ & $\mathrm{Y}$ & $\mathrm{Y}$ & $\mathrm{Y}$ & $\mathrm{Y}$ \\
Observations & 476743 & 476743 & 476743 & 476743 & 476743 & 476743 \\
\hline
\end{tabular}

The dependant variable is $\log (\#$ Fatalities +1$)$. Also included in regressions are Demographic + Geographic, Political + Ethnic controls (not including colonizer fixed effects), and country fixed effects. Spatial HAC standard errors reported. Coefficients and Standard Errors multiplied by 100 for reporting

$* p<0.1 ; * * p<0.05 ; * * * p<0.01$

Table 4 shows how the effect of $H H I(w)$ when varying the window size for $w \in\{50,60,80\}$. The results show that all ArgMins are interior, which means that the non-monotone effect of concentration is also found when looking at larger geographic scales. Moreover, when comparing ACLED to UCDP data sets when holding other things constant, the data set more associated with civil conflict (ACLED) has smaller ArgMins with larger window sizes. This supports the findings in the raw data that geopolitical monopolization is associated with increases in civil conflict.

The window size results in Table 4 also help distinguish between a larger number of partitioned ethnicities and a larger number of small countries (less geopolitical concentration). Whether the geocell had an ethnicity was partitioned is nearly indistinguishable from whether the geocell was on the border (partitioned groups are at a border while non-partitioned groups are not) which is also what is captured by HHI when the window size is very small (indicating whether the geocell is in a border region). But the measures diverge as the window size grows, which is where I find a more pronounced U-shape. This evidence suggests that partitioned ethnicities are not responsible for the findings in this paper. Alesina and Ferrara (2005) said "separation and country breakdown may be perfectly reasonable solutions to racial or cultural diversity", and this may supersede any effects from a one-time partition of ethnic boundaries. Further work would do well to compare the effects of ethnic partitions with geopolitical concentration. 


\section{Conclusion}

I find that there is more violence when there are many countries in an area, and less violence when there is only a single large country. However, violence diminishes at a diminishing rate and eventually reverses. This means 'more countries causes more violence' is the average relationship we observe, but often not the effect we should expect with more geopolitical concentration. The reason is that a net change in violence depends on the heterogeneous responses of different types of contestants (i.e., changes in both external and internal conflict). I have not argued that the geopolitical configuration that minimizes violence is socially optimal, and an association of political monopolization with repression or reduced growth would suggest a utilitarian optimum with less concentration. This paper is just a starting point for aggregating many different micro relationships in search of political geographies that promote peace and prosperity.

Future work can explore how internal preferences (i.e., ethnic resentments), market integration, and geopolitical concentration all interact to affect conflict. The growth channels examined by Bernholz et al. (1998), Bernholz and Vaubel (2005) are likely to be importantBecker (1998) said "competition among nations tends to produce a race to the top". Historically, both Renaissance Italy and Ancient Greece had a multitude of city-states with much flourishing despite their interstate confrontations, and it would be useful to systematically study whether the rates of overall conflict were higher than the neighboring regions during their respective periods. However, other mechanisms are also worth exploring. Political bargaining could be important, as many smaller countries may face high costs of bargaining between one another but fewer larger countries may face higher bargaining costs with their constituents. Path dependence could matter (especially if it is less costly to defend a resource once it has been acquired) which could make the effect of geopolitical concentration historically contingent. In general, further work is also needed to better understand under what conditions political mergers (and the joint exploitation of resources) are profitable. The framework developed in this paper is a promising approach for these further explorations.

Open Access This article is licensed under a Creative Commons Attribution 4.0 International License, which permits use, sharing, adaptation, distribution and reproduction in any medium or format, as long as you give appropriate credit to the original author(s) and the source, provide a link to the Creative Commons licence, and indicate if changes were made. The images or other third party material in this article are included in the article's Creative Commons licence, unless indicated otherwise in a credit line to the material. If material is not included in the article's Creative Commons licence and your intended use is not permitted by statutory regulation or exceeds the permitted use, you will need to obtain permission directly from the copyright holder. To view a copy of this licence, visit http://creativecommons.org/licenses/by/4.0/.

\section{Appendix}

\section{The contingent effects of concentration}

This section provides a a simple illustration for why the overall amount of violence depends on the competing internal versus external effects. Assume the resource values are constant, there are a continuum of locations to compete at, and (because it is easier for internal contestants to fight at the periphery) the inverse average costs in segment $\left(S^{i}, S^{i+1}\right]$ increase linearly from the center; $R(\ell) / \bar{c}(\ell)=R\left[A+B\left|\ell-\left(S^{i}+S^{i+1}\right) / 2\right|\right]$. In this case, the total amount of fighting effort from all players within a segment is 


$$
\int_{S^{i}}^{S^{i+1}} R\left(A+B\left|\ell-\frac{S^{i}+S^{i+1}}{2}\right|\right) d \ell=R\left[A\left(S^{i+1}-S^{i}\right)+\frac{B}{4}\left(S^{i+1}-S^{i}\right)^{2}\right] .
$$

The size of huge player $s^{i}=S^{i+1}-S^{i}$ is in terms of shares because the line segment of length 1 implies $\sum_{i} s^{i}=1$. This means the total amount of fighting effort in Eq. 5 reduces to

$$
\frac{N}{N+1}\left[\sum^{i} R\left(A s^{i}+\frac{B}{4}\left(s^{i}\right)^{2}\right)\right]=\frac{N R}{N+1}\left[A+\frac{B}{4} H H I\right],
$$

where $H H I=\sum_{i}\left(s^{i}\right)^{2}$. For a fixed $N$, total fighting effort is minimized at $s^{i}=1 / N \forall i$. Increasing $N$ in the fighting effort minimizing case where $s^{i}=1 / N$ (and thus $H H I=1 / N$ ) shows that when the spatial gradient of costs is high (because the tiny players have much lower costs in the periphery), increasing the number of countries $N$ leads to less violencenot more.

$$
\frac{d}{d N}\left[\frac{N R A}{N+1}+\frac{R B}{4(N+1)}\right]=\frac{R}{(N+1)^{2}}[A-B / 4] .
$$

Equation 14 is negative if $B / A>4$. The reason for this contingent comparative static is that internal contestants are included and the sizes of each state is affected when changing the sizes or numbers of other states.

\section{Other variables and violence}

This section examines other variables discussed in the literature. First, there are some noteworthy results for other variables in Table 3. To see this, Table 5 reports all coefficient estimates for the regressions in Table 3. Intuitively, population is a major factor. But also Lights and Diamonds (both of which could be associated with resources gained from controlling an area) are positively assocaited with conflict. There is also a positive association between areas that are majority Muslim and violence (compared to majority Christian). British and French areas are associated with less conflict. Finally, the coefficient for $H H I($ ethnic) is negative, which suggests that having fewer ethnicities in an area is also associated with less violence.

Yet, while ethnicity is an important facet of the fighting, the label 'ethnic conflict' has deflected critiques about the evidence and deterred exploring the economic and political factors that magnify or mitigate ethnic factors. Many ethnologists have argued that ethnicities are constructed and shaped based on political and economic factors (e.g., Barth 1969), which suggests there are important contingencies and some conflicts might misconstrued. ${ }^{17}$ Assefa (1996), for example, said "even if it were possible to define the actors in ethnic terms (if one were to define easily who the Amharas were), the reality on the ground does not support a conclusion that what was witnessed in Ethiopia was ethnic conflict." None of

\footnotetext{
17 Fearon and Laitin (2000) and Blouin and Mukand (2019) argued ethnicity is manipulable by governments. Congleton (1995) suggests that poor quality of governance would incentivize individuals to join ethnic groups, Landa (1981) suggests there would be more relational-contracting along ethnic lines as the formal sector faltered, and Shughart (2006) argued artificial nation states are responsible for terrorism.
} 
Table 5 Control variables and overall violence

\begin{tabular}{|c|c|c|c|c|c|c|}
\hline & ACLED & UCDP & ACLED & UCDP & ACLED & UCDP \\
\hline HHI & $\begin{array}{l}-3.15^{* *} \\
(1.30)\end{array}$ & $\begin{array}{l}-3.80^{\text {**** }} \\
(1.15)\end{array}$ & $\begin{array}{l}-3.20^{* * *} \\
(1.27)\end{array}$ & $\begin{array}{l}-3.95^{* * *} \\
(1.13)\end{array}$ & $\begin{array}{l}-1.12^{* *} \\
(0.47)\end{array}$ & $\begin{array}{l}-1.57 * * * \\
(0.45)\end{array}$ \\
\hline $\mathrm{HHI}^{2}$ & $\begin{array}{l}1.98 * * \\
(0.85)\end{array}$ & $\begin{array}{l}2.41 * * * \\
(0.75)\end{array}$ & $\begin{array}{l}1.97 * * \\
(0.83)\end{array}$ & $\begin{array}{l}2.53 * * * \\
(0.74)\end{array}$ & $\begin{array}{l}0.65^{* *} \\
(0.33)\end{array}$ & $\begin{array}{l}1.01 * * * \\
(0.31)\end{array}$ \\
\hline Lights & $\begin{array}{l}0.09 * * * \\
(0.03)\end{array}$ & $\begin{array}{l}0.06^{* *} \\
(0.02)\end{array}$ & $\begin{array}{l}0.09 * * * \\
(0.03)\end{array}$ & $\begin{array}{l}0.06^{* * * *} \\
(0.02)\end{array}$ & $\begin{array}{l}0.10^{* * * *} \\
(0.03)\end{array}$ & $\begin{array}{l}0.06^{* * *} \\
(0.02)\end{array}$ \\
\hline Population & $\begin{array}{l}46.22^{* * * *} \\
(7.03)\end{array}$ & $\begin{array}{l}23.32 * * * \\
(4.23)\end{array}$ & $\begin{array}{l}46.15^{* * *} \\
(7.04)\end{array}$ & $\begin{array}{l}23.21 * * * \\
(4.23)\end{array}$ & $\begin{array}{l}44.50 \text { *** } \\
(6.91)\end{array}$ & $\begin{array}{l}22.20 \text { *** } \\
(4.09)\end{array}$ \\
\hline Diamond & $\begin{array}{l}0.81 * * \\
(0.34)\end{array}$ & $\begin{array}{l}1.58 * * \\
(0.65)\end{array}$ & $\begin{array}{l}0.81 * * \\
(0.34)\end{array}$ & $\begin{array}{l}1.58 * * \\
(0.65)\end{array}$ & $\begin{array}{l}0.87 * * \\
(0.35)\end{array}$ & $\begin{array}{l}1.44 * * \\
(0.59)\end{array}$ \\
\hline OilGas & $\begin{array}{l}0.09 \\
(0.09)\end{array}$ & $\begin{array}{l}-0.06 \\
(0.07)\end{array}$ & $\begin{array}{l}0.06 \\
(0.09)\end{array}$ & $\begin{array}{l}-0.07 \\
(0.07)\end{array}$ & $\begin{array}{l}-0.005 \\
(0.10)\end{array}$ & $\begin{array}{l}-0.08 \\
(0.08)\end{array}$ \\
\hline Precip & $\begin{array}{l}-0.001 * \\
(0.0003)\end{array}$ & $\begin{array}{l}0.002 * * * \\
(0.001)\end{array}$ & $\begin{array}{l}-0.0004 \\
(0.0004)\end{array}$ & $\begin{array}{l}0.002 * * * \\
(0.001)\end{array}$ & $\begin{array}{l}-0.0003 \\
(0.001)\end{array}$ & $\begin{array}{l}0.001 * \\
(0.001)\end{array}$ \\
\hline CoastDist & $\begin{array}{l}0.29 * * * \\
(0.05)\end{array}$ & $\begin{array}{l}0.13^{* * * *} \\
(0.05)\end{array}$ & $\begin{array}{l}0.30 * * * \\
(0.06)\end{array}$ & $\begin{array}{l}0.15 * * * \\
(0.05)\end{array}$ & $\begin{array}{l}0.14 * * * \\
(0.05)\end{array}$ & $\begin{array}{l}-0.01 \\
(0.05)\end{array}$ \\
\hline TRI & $\begin{array}{l}0.001 * * * \\
(0.0003)\end{array}$ & $\begin{array}{l}0.001 * * * \\
(0.0002)\end{array}$ & $\begin{array}{l}0.001 * * * \\
(0.0003)\end{array}$ & $\begin{array}{l}0.001 * * * \\
(0.0002)\end{array}$ & $\begin{array}{l}0.001 * * * \\
(0.0002)\end{array}$ & $\begin{array}{l}0.001 * * * \\
(0.0002)\end{array}$ \\
\hline Lakes & $\begin{array}{l}0.09 \\
(0.15)\end{array}$ & $\begin{array}{l}-0.03 \\
(0.10)\end{array}$ & $\begin{array}{l}0.14 \\
(0.15)\end{array}$ & $\begin{array}{l}0.0004 \\
(0.10)\end{array}$ & $\begin{array}{l}-0.03 \\
(0.17)\end{array}$ & $\begin{array}{l}-0.07 \\
(0.13)\end{array}$ \\
\hline Sahara & $\begin{array}{l}-0.21^{* * *} \\
(0.04)\end{array}$ & $\begin{array}{l}0.11 * * \\
(0.05)\end{array}$ & $\begin{array}{l}-0.17 * * * \\
(0.05)\end{array}$ & $\begin{array}{l}0.17 * * * \\
(0.05)\end{array}$ & $\begin{array}{l}-0.15^{* * *} \\
(0.05)\end{array}$ & $\begin{array}{l}0.001 \\
(0.04)\end{array}$ \\
\hline CapitalDist & & & $\begin{array}{l}-0.0002 \\
(0.0002)\end{array}$ & $\begin{array}{l}-0.0003 * * \\
(0.0001)\end{array}$ & $\begin{array}{l}-0.0001 \\
(0.0001)\end{array}$ & $\begin{array}{l}-0.0002 * \\
(0.0001)\end{array}$ \\
\hline BorderDist & & & $\begin{array}{l}-0.02 \\
(0.08)\end{array}$ & $\begin{array}{l}-0.18^{* *} \\
(0.07)\end{array}$ & $\begin{array}{l}-0.11 \\
(0.16)\end{array}$ & $\begin{array}{l}-0.24 \\
(0.15)\end{array}$ \\
\hline HHI(ethnic) & & & $\begin{array}{l}-0.60^{* * * *} \\
(0.20)\end{array}$ & $\begin{array}{l}-0.57 * * * \\
(0.17)\end{array}$ & $\begin{array}{l}-0.78^{* * * *} \\
(0.23)\end{array}$ & $\begin{array}{l}-0.77 * * * \\
(0.19)\end{array}$ \\
\hline Slaves & & & $\begin{array}{l}-0.01 * * \\
(0.004)\end{array}$ & $\begin{array}{l}-0.01 * * \\
(0.004)\end{array}$ & $\begin{array}{l}-0.005 \\
(0.004)\end{array}$ & $\begin{array}{l}-0.003 \\
(0.003)\end{array}$ \\
\hline Tribal Religion & & & $\begin{array}{l}0.02 \\
(0.05)\end{array}$ & $\begin{array}{l}0.07 \\
(0.06)\end{array}$ & $\begin{array}{l}0.07 * \\
(0.04)\end{array}$ & $\begin{array}{l}-0.02 \\
(0.05)\end{array}$ \\
\hline Muslim Religion & & & $\begin{array}{l}0.17 * * * \\
(0.04)\end{array}$ & $\begin{array}{l}0.12 * * * \\
(0.04)\end{array}$ & $\begin{array}{l}0.16^{* * * *} \\
(0.06)\end{array}$ & $\begin{array}{l}0.08 * * \\
(0.04)\end{array}$ \\
\hline British & & & $\begin{array}{l}-0.21 * * * \\
(0.05)\end{array}$ & $\begin{array}{l}-0.15^{* * *} \\
(0.04)\end{array}$ & & \\
\hline French & & & $\begin{array}{l}-0.29 * * * \\
(0.05)\end{array}$ & $\begin{array}{l}-0.24 * * * \\
(0.05)\end{array}$ & & \\
\hline Country F.E. & $\mathrm{N}$ & $\mathrm{N}$ & $\mathrm{N}$ & $\mathrm{N}$ & $\mathrm{Y}$ & $\mathrm{Y}$ \\
\hline
\end{tabular}

The dependant variable is $\log (\#$ Fatalities +1$)$. Also included in some regressions are Demographic + Geographic controls, Political + Ethnic controls, or country fixed effects. Intercepts not reported. Spatial HAC standard errors reported. Coefficients and Standard Errors multiplied by 100 and rounded for reporting

$* p<0.1 ; * * p<0.05 ; * * * p<0.01$ 
Table 6 Geopolitical and ethnic concentration and overall violence

\begin{tabular}{lllllllll}
\hline & ACLED & UCDP & ACLED & UCDP & ACLED & UCDP & ACLED & UCDP \\
\hline HHI $(1945)$ & $-2.87^{* *}$ & $-3.21^{* * *}$ & & & $-2.87^{* *}$ & $-3.22^{* * *}$ & $-3.38^{* * *}$ & $-4.27^{* * *}$ \\
& $(1.16)$ & $(1.00)$ & & & $(1.16)$ & $(1.00)$ & $(1.25)$ & $(1.13)$ \\
HHI $(1945)^{2}$ & $1.80^{* *}$ & $2.02^{* * *}$ & & & $1.81^{* *}$ & $2.02^{* * *}$ & $1.75^{* *}$ & $1.89^{* * *}$ \\
& $(0.75)$ & $(0.65)$ & & & $(0.75)$ & $(0.65)$ & $(0.75)$ & $(0.63)$ \\
HHI(ethnic) & & & $-0.60^{* * *}$ & $-0.69 * * *$ & $-0.59^{* * *}$ & $-0.67 * * *$ & $-2.01^{* * *}$ & $-3.61^{* * *}$ \\
& & & $(0.20)$ & $(0.15)$ & $(0.20)$ & $(0.15)$ & $(0.68)$ & $(0.75)$ \\
HHI(1945) & & & & & & & $1.79 * *$ & $3.71 * * *$ \\
HHI(ethnic) & & & & & & & $(0.83)$ & $(0.89)$ \\
Dem. + geo. & $\mathrm{Y}$ & $\mathrm{Y}$ & $\mathrm{Y}$ & $\mathrm{Y}$ & $\mathrm{Y}$ & $\mathrm{Y}$ & $\mathrm{Y}$ & $\mathrm{Y}$ \\
Pol. + ethnic & $\mathrm{N}$ & $\mathrm{N}$ & $\mathrm{N}$ & $\mathrm{N}$ & $\mathrm{N}$ & $\mathrm{N}$ & $\mathrm{N}$ & $\mathrm{N}$ \\
Country F.E. & $\mathrm{N}$ & $\mathrm{N}$ & $\mathrm{N}$ & $\mathrm{N}$ & $\mathrm{N}$ & $\mathrm{N}$ & $\mathrm{N}$ & $\mathrm{N}$ \\
Observations & 476,743 & 476,743 & 476,743 & 476,743 & 476,743 & 476,743 & 476,743 & 476,743 \\
\hline
\end{tabular}

The dependant variable is $\log (\#$ Fatalities +1$)$. Also included in some regressions are Demographic + Geographic controls. Spatial HAC standard errors reported. Coefficients and Standard Errors multiplied by 100 for reporting

${ }^{*} p<0.1 ;{ }^{* *} p<0.05 ;{ }^{* * *} p<0.01$

this is to say that ethnicity is not an important part of the conflicts (as it surely is), but what features of the data are predicted by ethnicity is less straightforward.

The two largest issues, perhaps, surround ethnic-measurements and sample-selection. First, the assumption that ethnic groups comprise homogeneous and immobile populations exogenously placed is problematic. Barth (1969, p. 23), for example, said some sedentary Fur people in Sudan had changed to nomadic Buggara people-which suggests there could be serious statistical problems with the common approach of treating ethnicities as a unit of observation. But even if the spatial distribution of ethnicities were random, there would be correlations induced from larger units having higher counts and higher probabilities of observing events; i.e., larger ethnic territories would be more likely to be randomly partitioned and observe random conflicts. Second, when looking at cases of violence, there are different ethnicities involved (making ethnicity focal to many analysts) — but there are also many regions containing many ethnicities without much violence. The Democratic Republic of Congo is again a good example; as although there are many different ethnicities throughout the Congo, a large amount of the fighting occurs in the periphery. As such, the spatial variation in fighting is better explained by the costs and benefits for different military groups at different locations, rather than any universal propensity to kill another ethnicity.

By using a complete map of equal-area geocells, I help address the statistical issues and explore how ethnic heterogeneity interacts with geopolitical concentration. Moreover, I also consider that many of the same endogeneity issues for ethnic groups could be present for modern country boundaries. So to rule out biases from country boundaries being shaped by current conflict processes, I use an HHI based on the national borders set in 1945 (from Oracle's Think quest.org) — when the countries were still controlled by the colonial powers. The 1945 borders are very similar to the current borders (the HHI measures correlate $>.98$ at the geocell level) but occurred long before the current conflicts. Table 6 reports the results of regressions that include combinations of geopolitical and ethnic concentration; HHI(1945) and HHI(ethnic).

Table 6 shows that there is a role for ethnicity, but that the importance of ethnic heterogeneity depends on the geopolitical configuration. Specifically, the coefficient for ethnic concentration is smaller when only controlling for other demographic and geographic 
Table 7 Geopolitical concentration and overall violence by functional form

\begin{tabular}{|c|c|c|c|c|}
\hline & \multicolumn{2}{|l|}{ ACLED } & \multicolumn{2}{|l|}{ UCDP } \\
\hline & Onset & Intensity & Onset & Intensity \\
\hline HHI & $\begin{array}{l}-267.59 * * * \\
(18.66)\end{array}$ & $\begin{array}{l}2187.91 \text { *** } \\
(600.59)\end{array}$ & $\begin{array}{l}-412.11^{* * *} \\
(20.16)\end{array}$ & $\begin{array}{l}1934.79 \\
(2032.58)\end{array}$ \\
\hline $\mathrm{HHI}^{2}$ & $\begin{array}{l}170.39 * * * \\
(13.16)\end{array}$ & & $\begin{array}{l}255.00 * * * \\
(14.36)\end{array}$ & \\
\hline ArgMin & 0.77 & & 0.79 & \\
\hline Dem. + geo. & Y & & $\mathrm{Y}$ & \\
\hline Pol. + ethnic & $\mathrm{N}$ & & $\mathrm{N}$ & \\
\hline Country F.E. & $\mathrm{N}$ & & $\mathrm{N}$ & \\
\hline Observations & 476743 & & 476743 & \\
\hline
\end{tabular}

The dependant variables are 1(\#Fatalities $>0)$ and \#Fatalities. Also included in regressions are Demographic + Geographic controls. ArgMin estimates are based on a loess of the predicted fatalities (evaluated at the data). Classical standard errors reported. Coefficients and Standard Errors multiplied by 100 for reporting

$* p<0.1 ; * * p<0.05 ; * * * p<0.01$
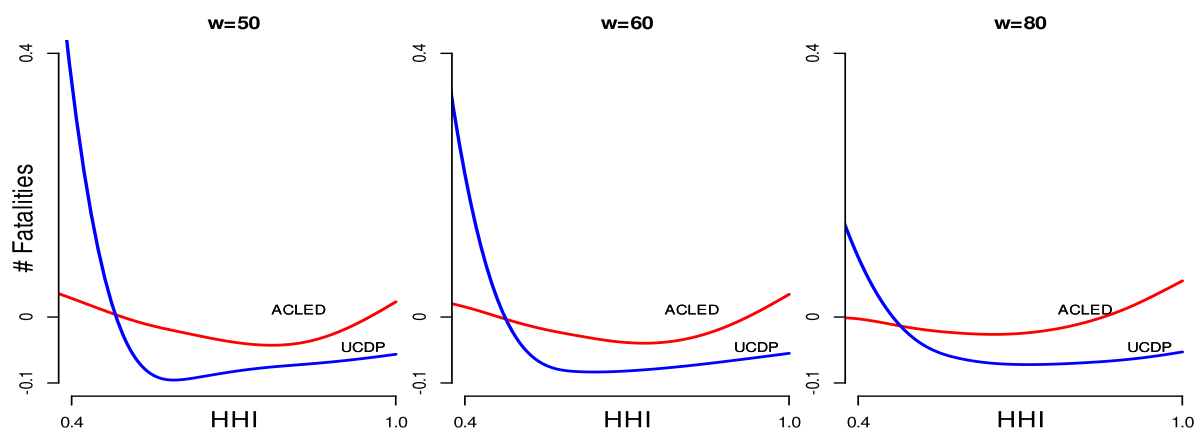

Fig. 5 Generalized additive model predictions, by window

factors, but becomes much larger when including interactions between ethnic and geopolitical factors. Table 6 also provides evidence that geopolitical concentration is independently important.

\section{Further results on functional form}

The body of the paper uses a log-linear functional form for easy comparisons and interpretations. In this section, I examine further non-linearities. I first estimate a Heckit model that accounts for the presence of zeros that can result from theoretical censoring: many corner solutions of non-violence, and empirical censoring: not recording events with few fatalities. Table 7 estimates both 'violence-onset', $P(\#$ Fatalities $>0)$, as well as 'violenceintensity', \#Fatalities|\#Fatalities $>0$. The table shows that the onset model estimates a quadratic relationship between $\mathrm{HHI}$ and violence-onset that is qualitatively similar to the 

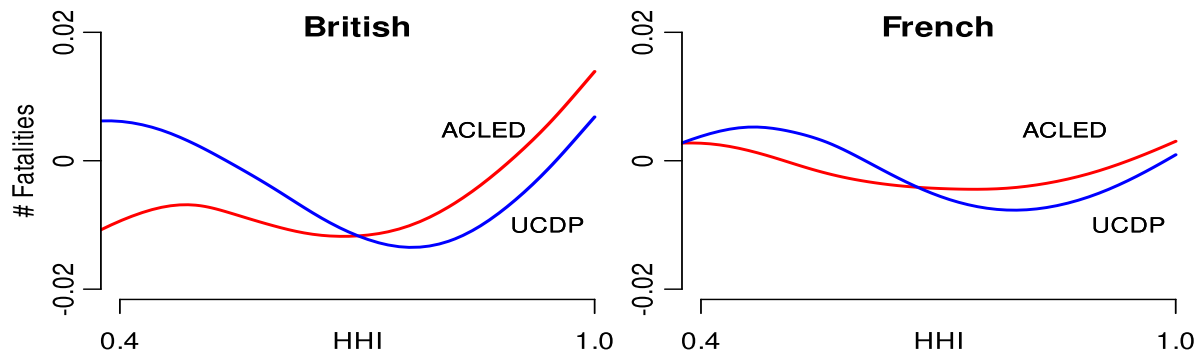

Fig. 6 Generalized additive model predictions, by colonizer

baseline. There is also a positive linear relationship between HHI and violence-intensity (after rejecting quadratic terms), which suggests geopolitical monopolization is associated with a higher intensity of conflict, conditional on a conflict occurring. Thus, while political monopolization suppresses the chance of conflict outbreak, it is associated with more intense fighting when it occurs. This matches the argument by Montesquieu (1748) that fragmentation helped diversify political risk.

I also estimate a generalized additive model (GAM) that uses a non-parametric spline smoother for the covariates HHI, Lights, Population, Diamond, Precip, CoastDist, and Ruggedness. Figure 5 shows the predicted level of violence over HHI with other terms partialled out. This figure shows a non-monotone relationship qualitatively similar to the baseline. Also in line with the main results, geopolitical monopolization over larger windows is associated with increases in conflict in the dataset more associated with internal conflict (ACLED).

I also estimate a generalized additive model (GAM) that uses a non-parametric spline smoother for HHI and a linear-term for all covariates. Figure 6 shows the predicted level of violence over HHI, with other terms partialled out, using only the data from geocells that were former British colonies or former French colonies. This figure shows a non-monotone relationship qualitatively similar to the baseline, although the relationship is contingent on the former colonies. If regions of British colonies traded more with one another than the French (as argued by de Sousa and Lochard 2012) then there would be a higher opportunity cost of conflict in those regions, which might mitigate any harmful effects of geopolitical monopolization. Figure 6 does not provide evidence for that mechanism, but further work is required to fully understand the different contingencies and their mechanisms.

\section{References}

Abramson, S. (2017). The economic origins of the territorial state. International Organization, 71(1), 97-130.

Adamson, J., \& Kimbrough, E. O. (2019). The supply side determinants of territory and conflict. Working paper. https://ssrn.com/abstract=3261667. Accessed 14 Dec 2019.

African Union Border Programme. (2014). Delimitation and demarcation of boundaries in Africa. 2nd ed. Addis Ababa: Commission of the African Union, Department of Peace and Security.

Alesina, A., Easterly, W., \& Matuszeski, J. (2011). Artificial states. Journal of the European Economic Association, 9(2), 246-277.

Alesina, A., \& Ferrara, E. L. (2005). Ethnic diversity and economic performance. Journal of Economic Literature, 43(3), 762-800. 
Alesina, A., \& Spolaore, E. (1997). On the number and size of nations. The Quarterly Journal of Economics, 112(4), 1027-1056.

Alesina, A., \& Spolaore, E. (2003). The size of nations. Cambridge: MIT Press.

Alesina, A., \& Spolaore, E. (2005). War, peace, and the size of countries. Journal of Public Economics, 89(7), 1333-1354.

Anderson, R. W., Johnson, N. D., \& Koyama, M. (2016). Jewish persecutions and weather shocks: 11001800. The Economic Journal, 127(602), 924-958.

Aristotle (350 B.C. [1885]). Politics. Trans. by B. Jowett. Web: The Internet Classics Archive.

Assefa, H. (1996). Ethnic conflict in the Horn of Africa: Myth and reality. In K. Rupesinghe \& V. Tishkov (Eds.), Ethnicity and power in the contemporary world. Shibuya-ku: United Nations University Press. Chap. 2.

Barth, F. (1969). Ethnic groups and boundaries: The social organization of culture difference. Long Grove: Waveland Press.

Becker, G. (1998). A euroskeptic speaks out. Hoover Digest, 4.

Berman, N., et al. (2017). This mine is mine! How minerals fuel conflicts in Africa. American Economic Review, 107(6), 1564-1610.

Bernholz, P. (1985). The international game of power: Past, present and future. Berlin: De Gruyter.

Bernholz, P., Streit, M., \& Vaubel, R. (1998). Political competition, innovation and growth: A historical analysis. Berlin: Springer.

Bernholz, P., \& Vaubel, R. (2005). Political competition, innovation and growth in the history of Asian civilizations. Ed. by P. Bernholz and R. Vaubel. Northamption: Edward Elgar Publishing.

Besley, T., \& Persson, T. (2014). The causes and consequences of development clusters: State Capacity, peace, and income. Annual Review of Economics, 6(1), 927-949.

Blouin, A., \& Mukand, S. W. (2019). Erasing ethnicity? Propaganda, nation building, and identity in Rwanda. Journal of Political Economy, 127(3), 1008-1062.

Boix, C. (2015). Political order and inequality: Their foundations and their consequences for human welfare. New York: Cambridge University Press.

Buhaug, H. (2006). Relative capability and rebel objective in civil war. Journal of Peace Research, 43(6), 691-708.

Buhaug, H., \& Gates, S. (2002). The geography of civil war. Journal of Peace Research, 39(4), 417-433.

Caselli, F., \& Coleman, W. J, I. I. (2013). On the theory of ethnic conflict. Journal of the European Economic Association, 11(s1), 161-192.

Caselli, F., Morelli, M., \& Rohner, D. (2015). The geography of interstate resource wars. The Quarterly Journal of Economics, 130(1), 267-315.

Centeno, A. C. (2002). Blood and debt: War and the nation-state in Latin America. University Park: Pennsylvania State University Press.

Center for International Earth Science Information Network-CIESIN-Columbia University, United Nations Food and Agriculture Programme, and Centro Internacional de Agricultura Tropical. (2005). Gridded population of the world, version 3 (GPWv3): Population count grid, future estimates. Palisades.

Christensen, D., \& Laitin, D. (2019). African states since independence: Order, development, and democracy. New Haven: Yale University Press.

Congleton, R. D. (1995). Ethnic clubs, ethnic conflict, and the rise of ethnic nationalism. In A. Breton, et al. (Eds.), Nationalism and rationality. Cambridge: Cambridge University Press.

Cunningham, D. E., \& Lemke, D. (2013). Combining civil and interstate wars. International Organization, 67(3), 609-627.

De La Sierra, R. S. (2017). On the origin of states: Stationary bandits and taxation in Eastern Congo. Working paper. https://ssrn.com/abstract=2358701. Accessed 14 Dec 2019.

de Sousa, J., \& Lochard, J. (2012). Trade and colonial status. Journal of African Economies, 21(3), 409-439.

Derex, M., Perreault, C., \& Boyd, R. (2018). Divide and conquer: Intermediate levels of population fragmentation maximize cultural accumulation. Philosophical Transactions of the Royal Society B: Biological Sciences, 373(1743), 20170062.

Dincecco, M., \& Prado, M. (2012). Warfare, fiscal capacity, and performance. Journal of Economic Growth, 17(3), 171-203.

Eberwein, W.-D., et al. (1979). External and internal conflict behavior among nations, 1966-1967. Journal of Conflict Resolution, 23(4), 715-742.

FAO et al. (2012). Harmonized world soil database (v 1.2). Web: FAO, IIASA, ISRIC, ISSCAS, JRC.

Fearon, J. D., \& Laitin, D. D. (2000). Violence and the social construction of ethnic identity. International Organization, 54(4), 845-877.

Fleck, R. K., \& Hanssen, F. A. (2013). When voice fails: Potential exit as a constraint on government quality. International Review of Law and Economics, 35, 26-41. 
Friedman, D. (1977). A theory of the size and shape of nations. Journal of Political Economy, 85(1), 59-77. Gat, A. (2006). War in human civilization. Oxford: Oxford University Press.

Gersovitz, M., \& Kriger, N. (2013). What is a civil war? A critical review of its definition and (econometric) consequences. Technical report.

Gilmore, E., et al. (2005). Conflict diamonds: A new dataset. Conflict Management and Peace Science, 22(3), 257-272.

Gleditsch, K. S. (2017). Civil war from a transnational perspective. Working paper. http://repository.essex .ac.uk/20067/. Accessed 14 Dec 2019.

Haaland, G. (1969). Economic determinants of ethnic processes. In F. Barth (Ed.), Ethnic groups and boundaries: The social organization of culture difference. Long Grove: Waveland Press. Chap. 3.

Hamilton, A. et al. (1787). The federalist papers. Web, Lillian Goldman Law Library.

Herbst, J. (2000). States and power in Africa: Comparative lessons in authority and control. Princeton: Princeton University Press.

Hijmans, R. J., et al. (2005). Very high resolution interpolated climate surfaces for global land areas. International Journal of Climatology, 25(15), 1965-1978.

Hillman, A. L. (2005). Political institutions, jurisdictional boundaries and rent creation. Keio Economic Studies, 41(1-2), 25-37.

Hirschman, A. (1945). National power and the structure of foreign trade. Berkeley: University of California Press.

Hirshleifer, J. (1995). Anarchy and its breakdown. Journal of Political Economy, 103(1), $26-52$.

Hornung, E. (2019). Diasporas, diversity, and economic activity: Evidence from 18th-century Berlin. Explorations in Economic History, 73, 101261.

Karayalçin, C. (2008). Divided we stand, united we fall: The Hume-North-Jones mechanism for the rise of Europe. International Economic Review, 49(3), 973-997.

Kisangani, E. (2016). Historical dictionary of the Democratic Republic of the Congo. New York: Rowman \& Littlefield Publishers.

Ko, C. Y., Koyama, M., \& Sng, T.-H. (2018). Unified China and divided Europe. International Economic Review, 59(1), 285-327.

Köonig, M. D., et al. (2017). Networks in conflict: Theory and evidence from the great war of Africa. Econometrica, 85(4), 1093-1132.

Konrad, K. A., \& Skaperdas, S. (2010). The market for protection and the origin of the state. Economic Theory, 50(2), 417-443.

Lacina, B. (2015). Periphery versus periphery: The stakes of separatist war. The Journal of Politics, 77(3), 692-706.

Landa, J. T. (1981). A theory of the ethnically homogeneous middleman group: An institutional alternative to contract law. The Journal of Legal Studies, 10(2), 349-362.

Levy, H., \& Markowitz, H. M. (1979). Approximating expected utility by a function of mean and variance. The American Economic Review, 69(3), 308-317.

Levy, J. S., \& Thompson, W. R. (2010). Causes of war. Chichester: Wiley-Blackwell.

Linard, C. et al. (2012). Population distribution, settlement patterns and accessibility across Africa in 2010. PLOS ONE, 7(2), e31743.

Lujala, P., Rød, J. K., \& Thieme, N. (2007). Fighting over oil: Introducing a new dataset. Conflict Management and Peace Science, 24(3), 239-256.

Mansfield, E. D. (1993). Concentration, polarity, and the distribution of power. International Studies Quarterly, 37(1), 105.

Meditz, S. W., \& Merrill, T. (1994). Zaire: A country study. Washington.

Michalopoulos, S., \& Papaioannou, E. (2016). The long-run effects of the scramble for Africa. American Economic Review, 106(7), 1802-48.

Montesquieu, C.-L. (1748). The spirit of the laws. Trans. by T. Nugent. New York: D. Appleton and Company.

Morris, I. (2014). War! What is it good for? Conflict and the progress of civilization from primates to robots. New York: Farrar, Straus and Giroux.

Murdock, G. (1959). Map of Africa. Digitized by Blier, Suzanne and Nunn, Nathan.

Nest, M., Grignon, F., \& Kisangani, E. F. (2006). The Democratic Republic of Congo: Economic dimensions of war and peace. Boulder: Lynne Rienner Publishers, Incorporated.

North, D. C. (1982). Structure and change in economic history. New York: W. W. Norton \& Company.

Nunn, N. (2008). The long-term effects of Africa's slave trades. The Quarterly Journal of Economics, 123(1), 139-176.

Nunn, N., \& Wantchekon, L. (2011). The slave trade and the origins of mistrust in Africa. American Economic Review, 101(7), 3221-52. 
Pinker, S. (2012). The better angels of our nature: Why violence has declined. New York: Penguin Books.

Powell, R. (2013). Monopolizing violence and consolidating power. Quarterly Journal of Economics, $128(2), 807-859$.

Prunier, G. (2008). Africa's world war: Congo, the Rwandan genocide, and the making of a continental catastrophe. New York: Oxford University Press.

Quinn, J. M. (2015). Territorial contestation and repressive violence in civil war. Defence and Peace Economics, 26(5), 536-554.

Raleigh, C., et al. (2010). Introducing ACLED: An armed conflict location and event dataset. Journal of Peace Research, 47(5), 651-660.

Richardson, L. F. (1960). Statistics of deadly quarrels. Ed. by Q. Wright and C. C. Lienau. Pittsburgh: Boxwood Press.

Robbins, L. (1939). Economic causes of war. London: Jonathan Cape.

Russell, B. (1936). Which way to peace?. London: Michael Joseph.

Seymour, L. J. (2014). Why factions switch sides in civil wars: Rivalry, patronage, and realignment in Sudan. International Security, 39(2), 92-131.

Shughart, W. F, I. I. (2006). An analytical history of terrorism, 1945-2000. Public Choice, 128(1), 7-39.

Silve, A., \& Verdier, T. (2018). A theory of regional conflict complexes. Journal of Development Economics, 133, 434-447.

Snidal, D. (1985). The limits of hegemonic stability theory. International Organization, 39(4), 579-614.

Spolaore, E. (2016). The economics of political borders. In Economic analysis of international law. Ed. by E. Kontorovich and F. Parisi. Edward Elgar Publishing. Chap. 1, 11-44.

Starr, H. (1994). Revolution and war: Rethinking the linkage between internal and external conflict. Political Research Quarterly, 47(2), 481-507.

Stearns, J. K. (2012). Dancing in the glory of monsters: The collapse of the Congo and the great war of Africa. New York: Public Affairs.

Sundberg, R., \& Melander, E. (2013). Introducing the UCDP georeferenced event dataset. Journal of Peace Research, 50(4), 523-532.

Tanter, R. (1966). Dimensions of conflict behavior within and between nations, 1958-60. The Journal of Conflict Resolution, 10(1), 41-64.

Tilly, C. (1990). Coercion, capital, and European states, AD 990-1992. Cambridge: Basil Blackwell.

Toft, M. D. (2014). Territory and war. Journal of Peace Research, 51(2), 185-198.

Tullock, G. (1974). The social dilemma: The economics of war and revolution (a public choice monograph). Blacksburg: University Publications.

Van Reybrouck, D. (2014). Congo: The epic history of a people. New York: Ecco.

Verwimp, P., Justino, P., \& Brück, T. (2018). The microeconomics of violent conflict. Journal of Development Economics, 4, 102297.

Voigtländer, N., \& Voth, H.-J. (2013). Gifts of mars: Warfare and Europe's early rise to riches. Journal of Economic Perspectives, 27(4), 165-186.

Waltz, K. N. (1979). Theory of international politics. Long Grove: Waveland Press.

Watch, H. R. (2008). World report. New York: 2008 Human Rights Watch.

Weidmann, N. B., \& Gleditsch, K. S. (2010). Mapping and measuring country shapes. The R Journal, 2(1), $18-24$.

Wilkenfeld, J. (1968). Domestic and foreign conflict behavior of nations. Journal of Peace Research, 5(1), 56-69.

Wittman, D. (1991). Nations and states: Mergers and acquisitions; dissolutions and divorce. The American Economic Review, 81(2), 126-129.

Publisher's Note Springer Nature remains neutral with regard to jurisdictional claims in published maps and institutional affiliations. 